\title{
BMJ Global Health Performance-based financing versus improving salary payments to workers: insights from the Democratic Republic of Congo
}

\author{
Rishma Maini, Sandra Mounier-Jack, Josephine Borghi
}

To cite: Maini $R$,

Mounier-Jack S, Borghi J. Performance-based financing versus improving salary payments to workers: insights from the Democratic Republic of Congo. BMJ Glob Health 2018;3:e000958. doi:10.1136/ bmjgh-2018-000958

Handling editor Seye Abimbola

Received 15 May 2018 Revised 25 July 2018 Accepted 27 July 2018

\section{SLinked}

- http://dx.doi.org/10.1136/ bmjgh-2017-000664

Check for updates

(c) Author(s) (or their employer(s)) 2018. Re-use permitted under CC BY-NC. No commercial re-use. See rights and permissions. Published by BMJ

Global Health Department, Faculty of Public Health and Policy, London School of Hygiene and Tropical Medicine, London, UK

Correspondence to Dr Rishma Maini;

mainirishma@gmail.com

\section{INTRODUCTION}

Performance-based financing (PBF) is a type of provider payment mechanism where a financial incentive is given to healthcare workers that is linked to performance. ${ }^{1}$ Also known as pay-for-performance $(\mathrm{P} 4 \mathrm{P})$, its use in low-income and middle-income countries has grown since 2005 when Rwanda adopted it as national policy. ${ }^{1}$ Well-designed PBF schemes can be accompanied by broader reforms, which aim to clarify roles and responsibilities, strengthen accountability and address certain structural problems facing health systems. ${ }^{1}$ However, a recent paper by Paul et al has raised concerns over the potential systemwide and long-term effects of $\mathrm{PBF}$, which may be damaging to health services in low-income and middle-income countries. ${ }^{2}$ This has led to a public debate on the evidence both for and against PBF in different settings, ${ }^{3}{ }^{4}$ and the authors would like to contribute to this by sharing an experience from the Democratic Republic of Congo (DRC).

\section{THE DRC CONTEXT}

Although the DRC has been post-conflict since 2003, its health system remains weak; hospitals and clinics lack personnel and equipment, and often run out of critical medicine and supplies. Few public sector health workers receive any government payments; this is due to the payroll being out of date and plagued by 'ghost workers', which are people listed on the payroll to receive a salary but who do not currently practice in health facilities. ${ }^{5}$ Therefore, in an effort to maintain health service delivery, donors have been implementing PBF schemes across the country for several years. Many of these have been delivered as stand-alone PBF programmes; for example, a previous health programme called Access

\section{Summary box}

Performance-based financing (PBF) has been extensively employed by donors in low-income and middle-income countries as a strategy to improve health service delivery.

- In the Democratic Republic of Congo, PBF is being implemented by donors and is endorsed by the Ministry of Health in a context where only a minority of health workers receive a government salary.

- A donor-funded health systems strengthening programme, which did not employ PBF, has recently succeeded in facilitating the payment of health workers by government.

- The programme achieved this by working closely with the government to conduct a census of health workers in order to update the payroll, which would in turn increase the number of salaried health workers.

- Key lessons learnt from this experience included the importance of understanding the existing financial architecture of health workers and its underlying constraints, and focusing on sustainable, national solutions rather than stand-alone donor-driven quick fix solutions, which may be more challenging to maintain over the longer term.

to Healthcare (ATH) funded by the Department for International Development (DFID) between 2008 and 2013 channelled payments to workers outside of the national system. By 2015, a quarter of all health zones were receiving $\mathrm{PBF}$ support from various different donors. ${ }^{6}$ Its roll-out has been endorsed by the Ministry of Health, but there is no national PBF scheme for the country as yet.

However, in the DRC, the evidence suggests that health workers do not value PBF payments as much as they do fixed salaries. ${ }^{78}$ Effects of PBF on performance have also been mixed in this context. In one study, PBF led to efficiency gains and improvements in service quality ${ }^{9}$; another study demonstrated 
that PBF did elicit an increase in efforts to target service provision, but did not stimulate demand for services, and even resulted in a reduction of intrinsic motivation of workers. $^{10}$

\section{AN ALTERNATIVE TO PBF}

In 2013, a new health systems strengthening programme funded by DFID called Accès Aux Soins de Santé Primaire (Access to Primary Healthcare/ASSP) commenced. In contrast to other donor programmes that were continuing with PBF or introducing follow-on PBF schemes, ASSP started to phase PBF out from its predecessor programme ATH. It was hypothesised that the presence of $\mathrm{PBF}$ - among other reasons including a low national budget for health, poor governance and security issueshad reduced incentives for the government to salary its health workers, thus potentially undermining systemwide reform in the sector. Instead, the ASSP programme worked closely with the government to conduct a census of health workers in order to update the payroll, which would in turn increase the number of salaried health workers. ${ }^{5}$

In practice, the phasing out of PBF proved difficult: it was perceived to have caused an exodus of workers from facilities as well as to have negatively affected their motivation and relationships with the local community. ${ }^{11}$ Part of the reason was that the change was poorly communicated, and performance payments were much higher than other sources of revenue received by workers including salaries, and so their removal constituted a significant economic shock to workers. ${ }^{811}$ Nonetheless, those workers who remained in facilities post-withdrawal of PBF indicated they would prefer to receive a fixed salary payment from the government compared with a performance payment from donors, as they saw the former as a more sustainable source of income. ${ }^{8}$

ASSP eventually succeeded in updating the health worker payroll for the provinces of Kasai and Kasai Central, as described by Likofata et al. ${ }^{5}$ Ghost worker payments were redistributed to thousands of previously undercompensated or uncompensated health workers in the civil service. However, the solution was not solely technical. The payment of health workers was outside the control of the Ministry of health, and under the purview of the Ministries of Finance, Budget and Public Sector Reform. Development partners involved in implementing ASSP therefore had to build relationships and work across these different Ministries, in order to secure government ownership and influence change. This was particularly crucial as there would have been vested interests within Ministries to maintain the status quo as salaries tend to be intricately tied to patronage and issues of political expediency. ${ }^{12}$ The DRC's Health Development Plan 2016-2020 also now acknowledges there is a continued need to strengthen information systems on human resources for health and improve on the number of salaried workers. ${ }^{13}$

\section{LESSONS LEARNT}

Several key lessons were learnt from this experience. First, PBF can serve as a distraction from the pursuit of more challenging interventions that are needed to address the underlying constraints of health systems. In the DRC, the financial compensation received by workers under donor-funded PBF schemes was effectively serving as a partial substitute for salaries, as only a minority of workers were being paid by the government; a similar analogy would be that of applying a plaster to an infected wound, rather than treating the underlying infection. The attraction of PBF for donors is understandable as it allows them to measure and demonstrate to their own governments and tax payers the results and value for money of their investments. On the other hand, interventions that require donors normally focused on health to work across several Ministries may seem less appealing.

Yet, a failure to address the problems at root can lead to a perpetuation of weak government leadership and accountability. ${ }^{14}$ In fragile and conflict-affected states such as the DRC, despite close coordination with government, PBF schemes are often still too complex for states to manage within their existing systems, and so involve the introduction of parallel systems to channel funding to providers and verify performance. Due to poor governance and accountability in the DRC, partners do not provide budget support; instead, PBF funds go directly into the accounts of health facilities. This results in PBF undermining rather than reinforcing state capacity. ${ }^{15}$ Furthermore, given that donor funding for performance-based incentives will in all likelihood eventually be withdrawn, there is the risk of creating a dependency on an income source that is not sustainable over the long term, with all the negative consequences that can entail.

Another lesson learnt was the need to understand the financial environment within which health workers operate when considering PBF initiatives. ${ }^{16}$ It has been acknowledged that PBF initiatives are often implemented as stand-alone projects without due consideration being given to the overall health system environment and their integration therein. ${ }^{17}$ Although the PBF model employed by the ATH programme did show evidence of improvements in performance over the short term, ${ }^{10}$ it could not have been sustainably financed in the absence of external aid. Soucat $e t$ al have highlighted the importance of understanding how PBF could be blended with the existing base payment mechanism to effectively align provider incentives with health policy objectives. ${ }^{17}$ This is key to ensuring that the system is structurally and financially sustainable; rather than adding extra income through a parallel system, existing income payments may be adjusted to make a proportion of it performance based. More recent innovations, like the Global Financing Facility which has started in the DRC, may also provide a good mechanism to support government efforts to enhance domestic resource mobilisation. ${ }^{18}$ The authors would argue, however, that the payment of 
salaries to workers should first be ensured before introducing more complex remuneration structures.

\section{CONCLUSION}

Donor-funded work to support the financing of health systems and its health workers should as far as possible address local priorities, be integrated into existing systems and seek to address root cause challenges, rather than focus on quick fix solutions such as stand-alone PBF schemes, which may be harder to sustain over time and could also lead to unintended consequences. This may require a commitment to working across Ministries and a willingness to prioritise sustainable national solutions over donor needs to quickly demonstrate results of aid.

Contributors RM drafted the initial manuscript. JB and SM-J reviewed and helped finalise the manuscript.

Funding The authors have not declared a specific grant for this research from any funding agency in the public, commercial or not-for-profit sectors.

Competing interests The lead author has recently been appointed as a health adviser for the Department for International Development (DFID). DFID funded the health systems strengthening programme referred to in the commentary.

Patient consent Not required.

Provenance and peer review Not commissioned; externally peer reviewed.

Data sharing statement This is not an original research article and thus no data are available.

Open access This is an open access article distributed in accordance with the Creative Commons Attribution Non Commercial (CC BY-NC 4.0) license, which permits others to distribute, remix, adapt, build upon this work non-commercially, and license their derivative works on different terms, provided the original work is properly cited, appropriate credit is given, any changes made indicated, and the use is non-commercial. See: http://creativecommons.org/licenses/by-nc/4.0/.

\section{REFERENCES}

1. Meessen B, Soucat A, Sekabaraga C. Performance-based financing: just a donor fad or a catalyst towards comprehensive health-care reform? Bull World Health Organ 2011;89:153-6.

2. Paul E, Albert L, Bisala BN, et al. Performance-based financing in low-income and middle-income countries: isn't it time for a rethink? BMJ Glob Health 2018;3:e000664.

3. Orange M. Towards a more balanced rethinking of performancebased financing. BMJ Global Health 2018. http://blogs.bmj.com/ bmjgh/2018/02/09/towards-a-more-balanced-rethinking-ofperformance-based-financing/?hootPostID=809dae051e182401 341de958313b0830 (accessed Mar 2018).

4. Mayaka S. Financement basé sur la performance: parlons-nous de la même chose?: Harmonisation for health in Africa blogs. 2018. http://www.healthfinancingafrica.org/home/financement-base-surla-performance-parlons-nous-de-la-meme-chose?utm source=IHP+ Newsletter\&utm_campaign=3e9fad1264-EMAIL_CAMPAIGN_2018 02 09\&utm medium =email\&utm term $=0$ 14504ce43d-3e9fad1264298053805 (accessed Mar 2018)

5. Likofata Esanga JR, Viadro C, McManus L, et al. How the introduction of a human resources information system helped the Democratic Republic of Congo to mobilise domestic resources for an improved health workforce. Health Policy Plan 2017;32:iii25-31.

6. World Bank. Democratic Republic of Congo, Revue de la Gestion des Dépenses Publiques et de la Responsabilisation Financière. 2015 (accessed Jun 2018).

7. Fox S, Witter S, Wylde E, et al. Paying health workers for performance in a fragmented, fragile state: reflections from Katanga Province, Democratic Republic of Congo. Health Policy Plan 2014;29.

8. Maini R, Hotchkiss DR, Borghi J. A cross-sectional study of the income sources of primary care health workers in the Democratic Republic of Congo. Hum Resour Health 2017;15:17.

9. Soeters R, Peerenboom PB, Mushagalusa P, et al. Performancebased financing experiment improved health care in the Democratic Republic of Congo. Health Aff 2011;30:1518-27.

10. Huillery E, Seban J. Financial incentives are counterproductive in non-profit sectors: evidence from a health experiment. 2015.

11. Maini R, J; Mounier-Jack S, Hotchkiss D, et al. Measuring the effects of withdrawing performance-based financing on the motivation of health workers in the Democratic Republic of Congo. 2018.

12. Trefon T. Administrative obstacles to reform in the Democratic Republic of Congo. Int Rev Ad Sci 2010;76:702-22.

13. DRC Ministry fof Health. Plan National de Développement Sanitaire 2016-2020. 2016. http://www.nationalplanningcycles.org/sites/ default/files/planning_cycle_repository/democratic_republic_of congo/pnds_2016-2020_version_finale_29_avril_2016.pdf (accessed June 2018)

14. Bräutigam D. Aid dependence and governance: expert group on development issues. 2000.

15. Bertone MP, Falisse JB, Russo G, et al. Context matters (but how and why?) A hypothesis-led literature review of performance based financing in fragile and conflict-affected health systems. PLoS One 2018;13:e0195301.

16. Bertone MP, Lurton G, Mutombo PB. Investigating the remuneration of health workers in the DR Congo: implications for the health workforce and the health system in a fragile setting. Health Policy Plan 2016;31:1143-51.

17. Soucat A, Dale E, Mathauer I, et al. Pay-for-performance debate: not seeing the forest for the trees. Health Systems \& Reform 2017;3:74-9.

18. World Bank. Global financing facility. Democratic Republic of Congo. (accessed Jun 2016). 